Competitive Victimhood in Response to Accusations of Ingroup Harmdoing

\title{
By
}

Daniel Luc Sullivan

Submitted to the graduate degree program in Social Psychology and the Graduate Faculty of the University of Kansas in partial fulfillment of the requirements for the degree of Master of Arts

Mark J. Landau, Chairperson

Committee members

Nyla R. Branscombe

Ann E. Cudd

Date defended: $\quad \underline{5 / 5 / 2010}$ 
The Thesis Committee for Daniel Sullivan certifies that this is the approved version of the following thesis:

\section{Competitive Victimhood in Response to \\ Accusations of Ingroup Harmdoing}

\section{Committee:}

Mark J. Landau, Chairperson

Nyla R. Branscombe

Ann E. Cudd

Date approved:__6/1/2010 


\begin{abstract}
Individuals are motivated to maintain a positive moral evaluation of social groups to which they belong. Accusations of unjust harmdoing on the part of the ingroup threaten the group's moral identity. One strategy for restoring ingroup moral identity after such a threat is competitive victimhood: claiming the ingroup has suffered as much or more than the harmed outgroup and other relevant groups. Two studies tested this process. In Study 1, male participants were more likely to claim that men are discriminated against compared to women after their group was accused of harming women. In Study 2, undergraduates were more likely to claim that their group is discriminated against compared to other campus groups after undergraduates were accused of harming university staff. Competitive victimhood did not occur when outgroup victimization was framed as the fault of the outgroup itself (Study 1) or a group other than the ingroup (Study 2).
\end{abstract}




\section{Acknowledgments}

Without the guidance of my friend and mentor, Dr. Mark Landau, I would be living somewhere else and studying different things. He was the first person I spoke to about the idea that would become the basis of this project (several years ago) and I cannot thank him enough. Dr. Nyla Branscombe has been a close collaborator from whom I have learned much, and I thank her sincerely for her help in developing this project from an idea to a reality. I must also thank Dr. Ann Cudd for her encouragement and for providing a fresh perspective that helps me keep my eye on the ultimate meaning of my work. I acknowledge an unpayable debt to my wonderful parents. Many, many thanks also to Leah Kapa, who was tremendously supportive to me throughout this project while working on her own thesis all the while. Finally, I should thank Kelsey Stappert and Elizabeth Finn, the research assistants who collected data for this project, and all the participants. 


\section{Table of Contents}

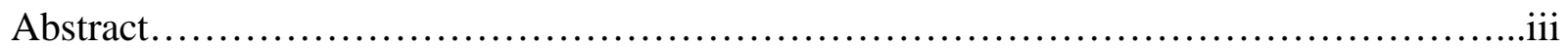

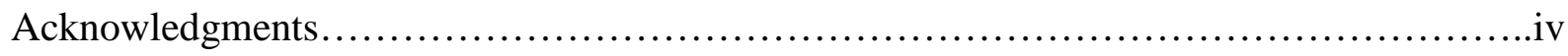

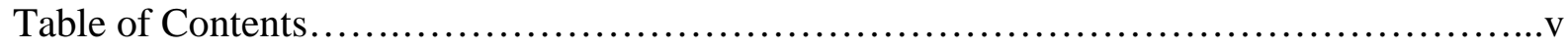

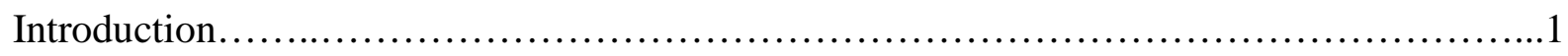

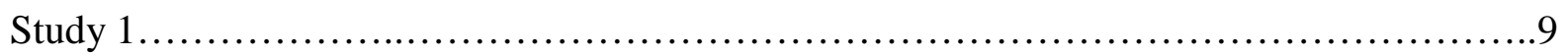

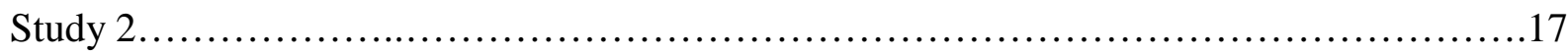

General Discussion.........................................................24

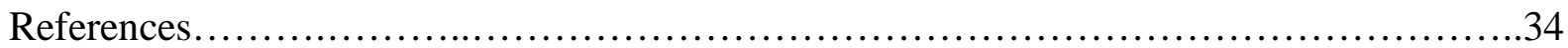

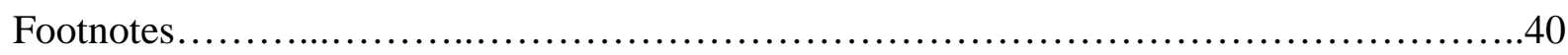

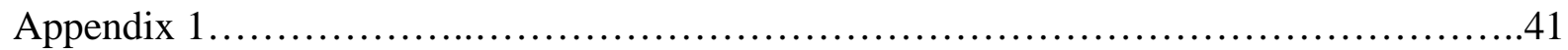

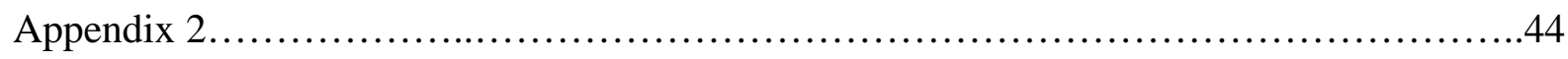

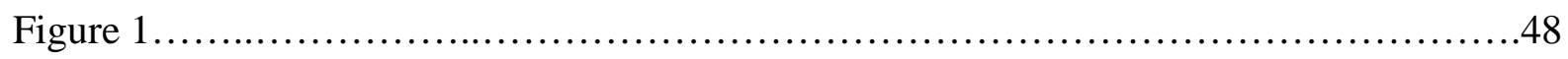

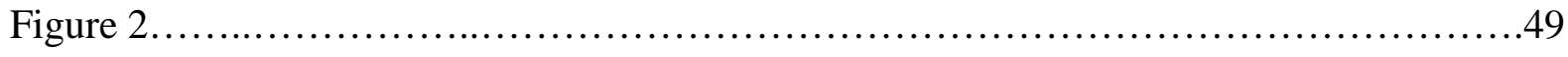




\section{Introduction}

"They began by reciting past injuries inflicted by the other group, as if competing to see who had suffered more."

- Vamik Volkan (1997, p. 32), describing the first meeting in the United States of Israeli and Egyptian representatives

Individuals are motivated to maintain a positive moral evaluation of their social group. When the ingroup is accused of committing unjustified harm against an outgroup, this can be a threat to social identity. In such circumstances, individuals will often strategically attempt to obtain higher moral standing for the ingroup in order to defuse the threat. In the modern era, one way of obtaining greater "moral credentials" for one's group (at least under certain circumstances) is through claims to relative victim status. As Volkan (1997) describes in the case of negotiations between Arab and Israeli leaders, claims of victimhood can imply that one's group deserves retribution, and can even serve to legitimate actions (such as war) which might otherwise seem unjustified. Thus an outgroup's claim to victimhood at the hands of the ingroup can pose a social identity threat in the form of an upward social comparison on the moral dimension. We hypothesize that this threat can be compensated for through competitive victimhood: claiming that one's ingroup has as much or more victim status than other relevant groups.

Ingroup moral status as a target for social identity threat

According to social identity theory, individuals define themselves largely in terms of the social groups with which they identify, and are motivated to maintain a positive conception of these groups (e.g., Tajfel \& Turner, 1986). Morality is perhaps the most important dimension on which the individual evaluates her ingroup(s). Supporting this idea, Leach, Ellemers and Barreto (2007) obtained evidence that a group's perceived moral status is more important for 
identification processes (e.g., taking pride in group membership) than a group's competence or sociability. In addition, studies show that people are more motivated to improve the status of their group when they perceive higher status as reflective of higher moral standing as opposed to higher competence (Ellemers, Pagliaro, Barreto, \& Leach, 2008).

Given that individuals are motivated to see the groups to which they belong as moral, it is psychologically threatening when the moral standing of one's group (relative to other groups) is called into question (Leach, Ellemers, \& Barreto, 2007). Prior work has shown that people are motivated to reduce or defend against such threats. For example, a growing body of research (e.g., Doosje et al., 1998; Wohl, Branscombe, \& Klar, 2006) suggests that experiencing guilt in connection with illegitimate, harmful actions taken by the ingroup motivates individuals to either legitimize the harm or take reparative action to compensate the outgroup. These processes stem from a desire to reduce internal distress arising from the perception that the ingroup has committed immoral acts (Miron, Branscombe, \& Schmitt, 2006), suggesting that an identity threat to the ingroup's moral status can be highly negative for the individual.

This body of work demonstrates that individuals experience a threat to their group's moral identity when reminded of negative ingroup actions, and that individuals are motivated to restore group moral identity in the wake of such threats. Such findings are consonant with research on moral credentials (Monin \& Miller, 2001). From this perspective, performing moral acts gives one a feeling of "credit" in a kind of psychological morality ledger. Such moral credentials are desirable not only because they affirm one's moral identity, but because this affirmation permits a lowered concern with one's moral standing in subsequent situations (Monin \& Miller, 2001). A guiltworthy or immoral act, on the other hand, implies a kind of moral "debt" which one is motivated to reduce in order to reestablish one's baseline moral 
identity (Carlsmith \& Gross, 1969; May, 1984; Rank, 1996). This understanding fits with Sachdeva, Iliev, \& Medin's (2009) theory of moral self-regulation, which posits that immoral acts require compensatory "moral cleansing," while moral acts provide a sense of "moral license" that alleviates a need to prove one's moral value in future situations.

Translating this analysis to the group level, knowledge that one's group has victimized an outgroup induces a personally-distressing sense of moral debt. The individual can either acknowledge this debt and attempt to repay it in some way, or she can attempt to void the debt using cognitive strategies such as legitimization or minimization of the harm suffered by the victim group. A third such "debt-avoidance" strategy proposed here is pursuing competitive victimhood.

\section{Claims to victimhood as competition for moral credentials}

Victim status - at least at first glance - appears predominantly negative and undesirable, given its implications of relative disadvantage, weakness, and low status, and indeed it has historically had such negative connotations (Fassin \& Rechtman, 2009). Nevertheless, in the current cultural climate, status as an undeserving victim of illegitimate harm might be somewhat desirable insofar as it appears to confer moral credentials (Strassel, 2001).

If a group or individual has suffered victimization, in our current society this often implies that this party has a right to expect reparations, either symbolic or material. Furthermore, victim status appears to afford a certain amount of moral license. Since a victim is by popular definition the opposite of a perpetrator (i.e., a victim has suffered some immoral act, as opposed to having committed one), a victim is not likely to be seen by others, or to see herself, as having a moral debt requiring reparative cleansing. Accordingly, Zitek, Jordan, Monin, and Leach (2010) found that perceiving oneself as victimized decreases one's likelihood of engaging in 
subsequent possible moral actions, an outcome mediated by feelings of entitlement resulting from one's victim status. Another potential source of the moral license implied by victimhood is the fact that while unprovoked displays of power and aggression tend to be condemned in current society, retaliatory aggression or collective action as a result of past victimization is often seen as acceptable and even laudable. This proclivity to champion victim action - even when it is violent - is likely related to the empirically-established preference of individuals for an "underdog" figure or group who triumphs, against the odds, over a powerful tyrant (Vandello, Goldschmied, \& Richards, 2007).

Thus victim status - beyond tending to keep one out of apparent moral debt - can actually give one moral license to commit acts that would normally be condemned, or at least to demand an acknowledgment of moral debt from one's oppressor (Moscovici \& Pérez, 2009). In general, belonging to a group that perpetrates negative acts against a victim group can induce a distressing sense of moral debt, while belonging to a victimized group can induce a positive sense of adequate or even high moral status. Partly supporting this idea, Branscombe (1998) found that reminding men of unfair advantages they possessed relative to women decreased their sense of ingroup well-being, while reminding men of ingroup victimization boosted their selfesteem.

Because of this phenomenon, modern social groups can often be observed "competing" through direct social comparisons along the moral dimension for public acknowledgment of greater victim status. Noor, Brown, \& Prentice (2008) refer to this tendency as competitive victimhood. These researchers have observed Catholics and Protestants in Northern Ireland attempting - through art, political addresses, and other media - to present the "definitive" 
version of local history, such that their group emerges as the "true" victim in a saga of mutual violence.

Working from an even broader sociological perspective, Cole (2007) has noted that, although modern attitudes towards claims to group victimhood are complex, "victim politics" are commonly used in the modern era to give moral credentials to a group, and to justify collective actions that might otherwise be seen as morally debt-incurring. For example, the ongoing debate regarding comparative moral justification for the use of military force among Israelis and Palestinians largely boils down to an argument over which group can lay greater claim to victim status (Nadler \& Shnabel, 2008). In the United States, the George W. Bush Administration drew upon claims to the country's victim status after the terrorist attacks of September $11^{\text {th }}, 2001$ to partly justify military invasions of Afghanistan and Iraq (Cole, 2007). Empirically, Wohl and Branscombe (2008) found that, for U.S. participants, reminders of ingroup victimization whether historical (the 1941 Pearl Harbor attack) or topical (the 9/11 attacks) - reduced feelings of collective guilt over current U.S. actions in Iraq. Similarly, reminders of past and current ingroup victimization increase feelings of collective forgiveness for harmful acts committed by the ingroup (Wohl \& Branscombe, 2009). Generally, it appears that - at least in the modern political sphere - claims to victimhood are often directly translatable to claims to moral credentials or license.

Although ideas of collective victimhood are integral to the social identities of members of certain groups (usually disadvantaged groups with a dramatic history of victimization, or groups in intractable conflicts; Bar-tal, Chernyak-Hai, Schori, \& Gundar, 2009; Volkan, 1997), conceptions of the ingroup as victimized probably do not form a core part of the identity of many members of high status groups in society. Nevertheless, the foregoing analysis suggests that 
under conditions of moral social identity threat, even members of higher status groups may engage in competitive victimhood in order to reaffirm the ingroup's moral standing relative to that of other groups. Since morality is a relatively ambiguous dimension (Nucci, 1996) that is subject to considerable influence from social comparison processes (Monin, 2007), people may seek to resolve aversive discrepancies between the moral standing of the ingroup and that of an outgroup by competing for moral credentials through claims to relative victimhood.

\section{Historical trends and complexity in attitudes toward victimhood}

The idea that victim status confers moral credentials, and that groups may therefore compete for it, is modern. Edmund Burke's (1790/1955) reflections on the rhetorical justifications employed during the French Revolution contain one of the first recorded formulations of this notion. A century later, Nietzsche (1887/2004) systematically investigated the phenomenon of ascribing higher moral status to victimized groups, concluding that it is the end result of a somewhat recent historical trend. Drawing on some etymological evidence (and a considerable amount of philosophical speculation), Nietzsche argued that, while concepts of "good" and "moral" were once associated with power and might, with the rise of Judeo-Christian religious thinking, humility, suffering, and martyrdom became more closely associated with the possession of high moral status.

Moscovici and Pérez (2009) use sociological data and theory to show that the rise of modern liberalism and the concept of "crimes against humanity" over the past three hundred years have led to a reversal of moral judgments of the powerful and powerless in society. These authors observe that while minority groups were once commonly labeled "deviant" and morally inferior, many minority groups now reject such labels to embrace the identity of morally entitled victims, an identity which gives them some cultural capital. For example, African Americans and 
Hindu Dalits ("untouchables") have a modern history of reinterpreting traditional theological narratives to equate their lower social status with higher moral standing (Mahalingam, 2007). At the same time, dominant groups once understood as "normative" are now commonly labeled guilty and immoral by virtue of their privileged status (see also Williams, 1993).

This general trend does not imply, however, that apparent victim status will always provide moral credentials for historically marginalized or underprivileged groups. Nietzsche's critique of victim or "slave" morality (as he calls it) is an intriguing case study in the complex modern attitudes towards victimhood investigated by Cole (2007). Specifically, while Nietzsche essentially criticizes Judeo-Christian groups for "inverting all values" and falsely equating victimhood with virtue, he is implicitly claiming high moral status for those powerful individuals in modern society - akin to the Ancient Greeks and Romans, who equated power with morality who are apparently the "true victims" of the Judeo-Christians' victim politics. Thus Nietzsche simultaneously condemns victim politics (explicitly) and practices it to suit his own interests (implicitly). Cole (2007) points to the Bush Administration's use of a similar rhetorical strategy, through which the U.S. obtained moral credentials for being the innocent victim of 9/11, but at the same time denied credentials to Al Qaeda by condemning their use of "victimist" polemics to recruit guerrillas for their ranks. Engaging in competitive victimhood while simultaneously decrying the rise of "privileged" victim identities, some members of high status social groups have come to believe in the complete reversal of traditional power structures: the empowered believe they have become the "true victims" in a society supporting reparative policies like affirmative action and diversity quotas (D'Souza, 1991; Lynch, 1989).

The complexity of modern attitudes about victimhood suggests that there are situations in which overt claims to victim status on the part of a marginalized group will not provide moral 
credentials for the group, nor be seen as threatening to dominant group members. The framing of victimhood may influence these outcomes. For example, when we engage in the process of blaming the victim - when victims are seen as deserving their own victimhood - then victim status no longer seems to infer higher moral standing (Harvey, 1995; Ryan, 1976). If victimhood is seen as undeserved, it implies a right to retribution, legitimization of activity that might otherwise be questionable, and greater moral credentials. If victimhood is understood as deserved, however, then this implies a potential lack of moral credentials to explain how the group became a victim group (or at least a lack of competence; for example, we can blame the urban poor for their status on grounds of either ignorance or deviant behavior patterns). Furthermore, if an outgroup's victim status is seen as deserved, the ingroup is absolved of responsibility, and does not incur any moral debt. This suggests that competitive victimhood should not occur in response to information suggesting that an outgroup is deservedly victimized, a hypothesis we will test in the current studies.

\section{The present research}

From the foregoing analysis, two major inferences can be drawn: 1) In the current cultural climate, victim status (when undeserved) affords a group moral credentials; and 2) because immoral (collective) acts elicit a sense of moral debt, exposure to a portrayal of an outgroup as victimized by the ingroup directly threatens one's moral identity as an ingroup member, by eliciting an upward social comparison in which the victimized outgroup appears to have moral credentials and the ingroup appears to have moral debt. These inferences yield a hypothesis: Exposure to a portrayal of an outgroup as undeservedly victimized by the ingroup should prompt the individual to engage in competitive victimhood to reduce the resulting upward social comparison in the moral sphere. 
Study 1 provides a test of the idea that members of an objectively high status group men - will claim greater ingroup victim status in comparison with the outgroup - women - when confronted with a portrayal of women as undeservedly victimized. This is a strong test of the competitive victimhood hypothesis, given that men are objectively higher status than women, and should not be motivated to make claims to group victimhood if such claims only imply a relative drop in status, rather than providing moral credentials (as we hypothesize). In Study 2 we sought to replicate this effect in another domain by examining the power/class hierarchy on a university campus, and to test whether competitive victimhood is a unique response to the moral identity threat posed by knowledge that the ingroup has illegitimately victimized another group. In both studies, perceptions of victim entitlement to material resources were measured, in an attempt to control for the possibility that claims to ingroup victimhood are driven by material, rather than moral, concerns.

\section{Study 1}

To the present day, women suffer various forms of social (Ellemers \& Barreto, 2009) and economic (Gittell, 2009) discrimination in the United States and around the world (United Nations, 2007), and remain a lower status group compared to men (e.g., Cudd, 2006). Nevertheless, as a paradoxical result of growing awareness of the reality of gender inequality, some men - despite their objectively higher status - have come to perceive themselves as victims of gender-based discrimination, often seen as stemming from policies and attitudes counteracting discrimination against women (Kobrynowicz \& Branscombe, 1997). As mentioned, contemplating such victimization of men based on their gender boosts men's self-esteem (Branscombe, 1998). 
From the present perspective, male perceptions of gender-based discrimination may be partly due to competitive victimhood processes. Specifically, we hypothesize that men engage in competitive victimhood with women when their ingroup is accused of doing harm to the outgroup. To test this hypothesis, we had male participants complete a short online study in which they first read an article which portrayed the outgroup as either non-victimized (i.e., discrimination against women no longer occurs), deservedly victimized (i.e., discrimination against women is the result of female characteristics and choices), or victimized by the ingroup (i.e., men are responsible for present discrimination against women). Participants were then presented with an opportunity to claim relative victim status for their group in comparison with the target outgroup. We expected that men confronted with information suggesting that they are responsible for discrimination against women would engage in greater competitive victimhood than men who were not confronted with such information. We anticipated this effect despite the fact that men comprise an objectively higher status group than women in modern U.S. society, and despite the superficially negative connotations of victim status. As implied by our theoretical analysis, we did not expect competitive victimhood to occur when victimization of women was framed as deserved, nor when women were described as non-victimized.

Given the aforementioned observation that victim status is often associated with notions of material entitlement in modern social consciousness (e.g., financial reparations; Cole, 2007), it is possible that our essay manipulation could influence the extent to which people see victims as entitled to material benefits, and that these perceptions might affect the likelihood of competitive victimhood. The more people think victims are entitled to material resources in our society, the more they might want to claim relative victim status for the ingroup. Contrary to this proposition, our analysis expects competitive victimhood to occur in response to moral threat, and not as a 
function of material concerns. To test these differential predictions, we included a measure of perceive victim entitlement to material resources.

\section{Method}

Forty-nine University of Kansas male undergraduates were randomly assigned to one of three conditions (portrayal of outgroup: non-victimized vs. self-victimized [victimhood deserved] vs. victimized by the ingroup) in a single-variable between-subjects design, with competitive victimhood as our dependent measure of interest. All data were collected online through the university SONA System.

In an ostensible study of perspectives on gender issues, participants completed an online survey designed using Survey Monkey. Participants first completed a few filler measures (designed to distract from the central purpose of the study) and a five-item measure of identification as a man ("I often think of myself in terms of being a man," "Being a man is an important reflection of who I am," "In general, being a man is an important part of my selfimage," "I identify with other men," "I feel strong ties with other men;" $1=$ Strongly disagree, 7 $=$ Strongly agree $; \alpha=.94)$. This measure was included not only to test for any possible moderation by ingroup identification - we expected none - but also to prime participants' category membership.

Outgroup portrayal (threat to the ingroup) manipulation. Participants then read a fabricated news article reporting on the status of women in modern society. This article served as the independent variable, and was based on a prior manipulation of perceptions of outgroup discrimination (Schmitt, Branscombe, \& Postmes, 2003). Specifically, participants were randomly assigned to read one of three possible news articles (with the author's gender unspecified; see Appendix 1 for full text of each article). 
In the non-victimized condition, the article argued that women and men have equal opportunities for success in modern society, and no mention was made of any group victimization. This portrayal of the outgroup served as one of two comparison conditions designed to imply no moral threat to the ingroup.

In the self-victimized (deserved victimhood) condition, the article argued that women are discriminated against in modern society, but this discrimination stems from aspects of their own biology and life choices. This article contained passages like: "As a result of biological differences and choices made by women based on those differences, women are victims of widespread discrimination in the workplace and other areas to this day. Due to certain inherent characteristics, women experience discrimination despite the fact that men are not responsible for its occurrence." This portrayal of the outgroup served as the second of two comparison conditions designed to imply no moral threat to the ingroup.

In the victimized by the ingroup condition, the article argued that women are victims of discrimination intentionally perpetrated by men. This article contained passages like: "As a result of the behaviors and prejudices of men at all levels of society, women are victims of widespread discrimination in the workplace and other areas to this day. Because men have an active interest in maintaining their social advantages, discrimination of women continues to occur." This portrayal of the outgroup was designed to present a moral threat to the ingroup.

Manipulation checks. Participants then completed three manipulation check items to assess the effectiveness of the essay manipulation. Specifically, participants rated their level of agreement (on a 7-point scale) with the following statements: "In the article you read, women were described as victims of discrimination," "In the article you read, women were described as being responsible for the discrimination they experience," and "In the article you read, the 
discrimination women experience was described as being the result of men's actions." To assess whether our outgroup portrayal manipulation effectively varied the degree of perceived threat, we additionally asked, "Many men would feel threatened by the article that you read."

Competitive victimhood. Participants then completed a single-item measure of competitive victimhood: "In society, compared to women, men experience discrimination" $(1=$ less overall, $4=$ as much, $7=$ more overall $)$.

Perceptions of victim material entitlement. At the end of the survey we included two items assessing perceptions of victim material entitlement to test for any effect of the manipulation on these perceptions. Specifically, participants rated their level of agreement (on a 7-point scale) with the following statements: "In our society, victims of discrimination are generally entitled to certain resources, such as financial reparations or increased political power," and "Our society is generally willing to give compensation to groups perceived as having suffered discrimination." These two items correlated significantly $(p<.001)$ at $r=.63$, and were combined to form a single measure of perceptions of victim material entitlement.

After completing all measures, participants received a thorough debriefing explaining the purpose of the experiment, and the fact that the essay was fabricated for the study. Results and discussion

Manipulation checks. To test the effectiveness of the manipulations, one-way ANOVAs (portrayal of outroup: non-victimized vs. self-victimized vs. victimized by the ingroup) were conducted on each of the manipulation check items. A significant result was found for the item, "In the article you read, women were described as victims of discrimination," $F(2,46)=11.42, p$ $<.001$. Pairwise comparisons revealed that participants in the self-victimized and victimized-bythe-ingroup conditions agreed more strongly with this statement compared to participants in the 
non-victimized condition, $t \mathrm{~s}>4.0, p \mathrm{~s}<.01$, while participants in the victimized conditions did not differ significantly in their level of agreement, $p=.87\left(M_{\text {Non-victimized }}=2.50 ; M_{\text {Self-victimized }}=\right.$ 5.33; $M_{\text {Victimized by the ingroup }}=5.22$ ). For the item, "In the article you read, women were described as being responsible for the discrimination they experience," we also found a significant difference, $F(2,46)=8.71, p<.01$, such that participants in the self-victimized condition agreed more strongly with this statement compared to all other participants, $t \mathrm{~s}>3.36, p \mathrm{~s}<.01$, while participants in the non-victimized and victimized-by-the-ingroup conditions did not differ in their level of agreement, $p=.53\left(M_{\text {Self-victimized }}=4.13 ; M_{\text {Non-victimized }}=2.00 ; M_{\text {Victimized by the ingroup }}=\right.$ 2.33). For the item, "In the article you read, the discrimination women experience was described as being the result of men's actions," we also obtained a significant result, $F(2,46)=6.19, p<$ .01. Participants in the victimized-by-the-ingroup condition agreed more strongly with this statement compared to all other participants, $t \mathrm{~s}>2.65, p \mathrm{~s}<.02$, while participants in the nonvictimized and self-victimized conditions did not differ significantly in their level of agreement, $p=.51\left(M_{\text {Victimized by the ingroup }}=4.89 ; M_{\text {Non-victimized }}=3.13 ; M_{\text {Self-victimized }}=2.67\right)$. Finally, we obtained a significant result on the measure of perceived threat, $F(2,46)=8.21, p<.01$. As predicted, participants in the victimized-by-the-ingroup condition saw the article as more threatening compared to participants in the other conditions, $t \mathrm{~s}>3.12, p \mathrm{~s}<.01$, while participants in the non-victimized and self-victimized conditions did not differ in perceived threat, $p=.58\left(M_{\text {Victimized by the ingroup }}=3.72 ; M_{\text {Non-victimized }}=2.00 ; M_{\text {Self-victimized }}=2.27\right)$.

Competitive victimhood. A one-way ANOVA was performed on the single-item measure of competitive victimhood, which yielded a significant result, $F(2,46)=3.18, p=.05, \eta^{2}=.12 .^{1}$ As predicted, pairwise comparisons revealed that participants in the victimized-by-the-ingroup condition engaged in significantly more competitive victimhood $(M=2.61, S D=1.61)$ 
compared to participants in the non-victimized $(M=1.69, S D=.79 ; t(46)=2.37, p=.02)$ and self-victimized conditions $(M=1.87, S D=.63 ; t(46)=1.87, p=.06)$. Means for the nonvictimized and self-victimized condition participants did not differ, $t<1, p=.66$ (see Figure 1 for a graphical depiction of these results).

Perceptions of victim material entitlement. Performing the same analysis on the dual-item composite of perceptions of victim entitlement to material resources did not yield a significant result, $F(2,46)<1, p=.58\left(M_{\text {Non-victimized }}=3.88 ; M_{\text {Self-victimized }}=4.12 ; M_{\text {Victimized by the ingroup }}=3.67\right)$. Interestingly, perceptions that victims are materially entitled correlated negatively (but nonsignificantly) with competitive victimhood, $\mathrm{r}=-.13, p=.37$.

Male participants exposed to a portrayal of women as undeservedly victimized by the ingroup (men) felt more morally threatened, and were more likely to engage in competitive victimhood, compared to participants in the non-victimized and self-victimized portrayal conditions. Participants exposed to a portrayal of women as deservedly victimized, however, were not more likely to engage in competitive victimhood compared to men in the nonvictimized control condition. Furthermore, preliminary evidence was found that claims to group victimhood are not related to perceptions of mere material entitlement, suggesting that competitive victimhood can be a psychological strategy to defend against moral threat independent of desire for power or financial gain.

The real-world implications of this particular study are somewhat obvious, given that the operationalizations expressly involved two widely recognized social groups that are often conceived of as existing in a victimizer-victim relationship (men and women). However, one potential limitation of this design stems from the zero-sum nature of a (relatively) dichotomous grouping variable like gender. According to our analysis, competitive victimhood is a strategy 
for restoring the ingroup's moral identity when the ingroup is accused of causing the undeserved victimization of an outgroup. This perspective suggests that if an outgroup is undeservedly victimized by another group (i.e., not by the ingroup), no special motivation to engage in competitive victimhood will be aroused (because no moral debt has been incurred by the ingroup). However, because victimization in dichotomous groups is necessarily either the ingroup's (from the perspective of our study, men's) fault or is in some sense deserved by the outgroup (in the study, women portrayed as victims of their own choices, biology etc.), it is difficult to examine the unique importance of ingroup responsibility for the outgroup's undeserved victimization in this context. If women are undeservedly victimized (meaning they are not to blame for their victimization), then almost by necessity their victimization is the fault of men.

In the case of non-dichotomous groups, however, responsibility for undeserved victimization may lie in a number of places. To take the example of national identity, a U.S. citizen who perceives immigrants to her country as victimized (through discriminatory practices etc.) may trace the fault for this victimization either back to the victims themselves (self- or "deserved" victimization), to the ingroup, or to some third group (for example, she may see immigrants as undeserving victims of oppressive regimes in their native countries which forced their immigration). This aspect of non-dichotomous groups suggests a possibility we were unable to test in Study 1, namely, that ingroup responsibility for an outgroup's undeserved victimization might not be necessary for competitive victimhood to occur. If status as an undeserving victim does in fact confer moral credentials, then it's possible that individuals will engage in competitive victimhood after exposure to a portrayal of an outgroup as undeservedly victimized by any group, and not only by the ingroup. However, if competitive victimhood claims are 
uniquely motivated by an incurred moral debt - as our analysis suggests - then they should only follow from perceptions that the ingroup is responsible for outgroup victimization.

In Study 2, then, we attempted to replicate and extend our first investigation by examining competitive victimhood processes in a context involving multiple groups: the class/power hierarchy within a university setting. By doing so, we were able to examine whether competitive victimhood occurs only in response to portrayals of an outgroup as victimized by the ingroup, or whether this tendency might be activated by portraying an outgroup as undeservedly victimized by any group. An additional advantage of examining competitive victimhood in a context involving non-dichotomous groups is that we were able to determine whether the competitive victimhood strategy only involves competition with the victimized outgroup, or whether this motivated competition extends to comparisons with other groups as well.

Study 2

In a field study at the State University of New York at Albany, Tompkins, Fisher, Infante, \& Tompkins (1975) found evidence for psychological perceptions of a hypothesized hierarchy existing within the university system. Specifically, these researchers asserted that administrators (including directors and college deans) form a "high status" group on campus, civil service workers or "staff" (secretaries and maintenance workers) form a relative "low status" group, and students fall somewhere in between (see Bess \& Dee, 2008, for an extended discussion of power relationships within a university setting). In Study 2, we used this naturally occurring multi-group power hierarchy to further test competitive victimhood processes. Specifically, we hypothesized that a higher status group (undergraduate students) would be more motivated to engage in competitive victimhood after being accused of illegitimately harming an outgroup (university staff, a lower status group). 
Beyond testing the motivation for competitive victimhood in a different domain, Study 2 also expands on Study 1 in multiple ways. First, as mentioned, because Study 2 examines motivation for competitive victimhood in a non-dichotomous groups context, we were able to better test whether the effect is uniquely driven by accusations of ingroup responsibility for the victimization of an outgroup. Having established in Study 1 that competitive victimhood does not follow from information suggesting that the outgroup is deservedly victimized, in Study 2 we instead focused on testing whether competitive victimhood follows from portrayal of the outgroup as undeservedly victimized by any group (and not only by the ingroup). Specifically, we hypothesized that undergraduate students would engage in competitive victimhood when their ingroup had been accused of victimizing the outgroup (university staff), but not when another group (university administrators) had been accused of victimizing the outgroup (because, in the latter case, no moral debt on the part of the ingroup is implied).

Secondly, in Study 2 we controlled for a possible alternative explanation of the Study 1 finding. It is possible that contemplating ways in which the ingroup has victimized an outgroup simply increases the overall salience of the ingroup's experiences with victimhood. In other words, rather than competitive victimhood being a motivated process whereby individuals attempt to reduce the apparent moral gap between ingroup and outgroup after accusations of ingroup harmdoing - as we claim - competitive victimhood might simply be the byproduct of a non-motivated increase in the overall salience of the ingroup's victimhood.

There are two reasons why we do not believe this to be an adequate explanation of competitive victimhood as observed in Study 1. First, the concept of victimhood was made equally salient in both the self-victimized and victimized-by-the-ingroup conditions; the amount of discrimination experienced by the outgroup was described as the same in each induction, and 
only the alleged source of the discrimination varied. Nevertheless, more competitive victimhood was observed in the victimized-by-the-ingroup condition compared to the self-victimized and no victimization conditions. This pattern of results would be unlikely if our competitive victimhood measure was simply assessing overall salience of victimhood.

Second, and more importantly, even if there was some unique aspect of priming the ingroup's victimization of the outgroup that led to increased salience of ingroup victimhood, we would expect such a process to be quite different from the motivated, comparative process of competitive victimhood. Our analysis suggests that competitive claims to victimhood are motivated by a moral identity threat which they resolve by establishing the moral credentials of the ingroup relative to other groups. In short, from our perspective, the "competitive" aspect of competitive victimhood is essential; claims to group victimhood that do not establish the ingroup's victimhood in reference to the victimhood of other groups cannot fulfill the moral social comparative function posited to lie at the heart of the process.

In order to provide a stronger test of the moral comparative aspect of competitive victimhood, and control for the possibility that salience of ingroup harmdoing simply increases salience of ingroup victimhood, in Study 2 we differentiated between noncompetitive and competitive claims to group victimhood. Specifically, we asked participants separately about their perceptions of the ingroup - University of Kansas undergraduates - as victimized without reference to any other group (noncompetitive victimhood), and in reference to other relevant groups in the university setting: the target outgroup - university staff - as well as faculty and graduate students (competitive victimhood). Because perceptions of the ingroup as victimized without reference to any outgroup do not serve a direct moral comparative function, we did not expect accusations of ingroup harmdoing to increase noncompetitive victimhood. However, 
because competitive claims to ingroup victim status relative to any relevant outgroup do comparatively boost the ingroup's moral credentials, we expected accusations of ingroup harmdoing to increase competitive victimhood in reference to all outgroups (staff, faculty, and graduate students).

\section{Method}

Thirty-two University of Kansas undergraduates (fourteen female) were randomly assigned to one of three conditions (portrayal of outgroup: non-victimized vs. victimized by another group vs. victimized by the ingroup) in a single-variable between-subjects design, with competitive victimhood as our dependent measure of interest.

Portrayal of outgroup (threat to the ingroup) manipulation. Participants entered a laboratory to take part in an ostensible study on perceptions of campus life. In the first part of the study, participants used headphones to listen to an ostensible audio report prepared by campus researchers on the computer. The prerecorded audio report (fabricated by the experimenters) concerned treatment of university staff, and served as our manipulation (see Appendix 2 for a transcript of the audio report in each condition). Across conditions, the report began with narration describing an alleged study that had been conducted on campus to investigate the treatment of non-student university staff. The study was reputed to have been conducted by researchers from different departments at the university, and to have involved nonobtrusive observation of and interviews with 100 staff members, as well as surveys and interviews with administrators, faculty, and students.

In the non-victimized condition, the narrator of the report stated that the results of the study indicated that "overall, the KU staff receives treatment that is comparable to that of the members of many other university staffs around the country. In particular, KU staff members 
receive fair treatment from students and administrators." Later, in an alleged interview segment, an ostensible staff member (voiced by one of the experimenters) responded to a question about staff treatment by stating: “Overall I'd say it's pretty good. I worked in different jobs, and even at different universities for years now, and I feel treated just as good at KU as anywhere else. Most people are fairly decent to you." This report served as one of two comparison conditions designed to imply no moral threat to the ingroup.

In the victimized by another group condition, the narrator of the report stated that the results of the study indicated that "overall, the KU staff suffers worse treatment than the members of many other university staffs around the country. In particular, KU staff members receive harsh treatment from the campus administration. Representatives of the administration were routinely observed publicly humiliating or verbally abusing campus staff." In the interview segment the ostensible staff member stated: “Overall I'd say [treatment of staff on campus] is pretty bad. I worked in different jobs, and even at different universities for years now, but I never been treated worse than here at KU. The administrators here just walk all over you!" This report served as the second of two comparison conditions designed to imply no moral threat to the ingroup.

Finally, in the victimized by the ingroup condition, the narrator of the report stated that the results of the study indicated that "overall, the KU staff suffers worse treatment than the members of many other university staffs around the country. In particular, KU staff members receive harsh treatment from the undergraduate student population. Undergraduates were routinely observed publicly humiliating or verbally abusing campus staff." In the interview segment the ostensible staff member stated: "Overall I'd say [treatment of staff on campus] is pretty bad. I worked in different jobs, and even at different universities for years now, but I never 
been treated worse than here at KU. The undergrads here just walk all over you!" This report was designed to present a moral threat to the ingroup.

Perceptions of victim material entitlement. After listening to the audio report, participants completed a measure presented as a "Campus Life Survey." The first item on the survey referred directly to the audio report, and measured perceptions that the victim status of the outgroup might make outgroup members eligible for material benefits: "If the results of this study were made public, it could ultimately lead to benefits for KU staff, like higher wages and more vacation time" ( $1=$ strongly disagree, $7=$ strongly agree $)$. This item allowed us to control for the possibility that any tendencies toward competitive victimhood were driven by perceptions that victims receive material benefits.

Noncompetitive and competitive victimhood. Participants then completed three items measuring noncompetitive victimhood claims on behalf of the ingroup: "At times, I feel negatively discriminated against because of my status as an undergraduate student," "KU undergraduates are discriminated against on campus because of their status as students," and "KU undergraduates are discriminated against off campus, in other areas of Lawrence, because of their status as students" $(1=$ never, $4=$ sometimes, $7=$ frequently $)$.

These items were followed by three items measuring competitive victimhood claims, one of which measured competition with the target outgroup, and two of which measured competition with unrelated outgroups: "Compared to KU staff, KU undergraduates experience discrimination," "Compared to KU graduate students, KU undergraduates experience ___ discrimination," and "Compared to KU faculty, KU undergraduates experience __ discrimination" $(1=$ less overall, $4=$ as much, $7=$ more overall $)$. 
Each set of three items was averaged to create two composite measures of noncompetitive ( $\alpha=$ $.85)$ and competitive $(\alpha=.85)$ victimhood.

After completing the survey, participants were debriefed concerning the true purpose of the study, and the fact that the audio report was fictitious.

Results and discussion

Noncompetitive victimhood. A one-way ANOVA (portrayal of outgroup: non-victimized vs. victimized by another group vs. victimized by the ingroup) on our composite measure of noncompetitive victimhood yielded a non-significant result, $F(2,29)=.91, p=.42\left(M_{\text {Non-victimized }}\right.$ $=1.73 ; M_{\text {Victimized by another group }}=2.28 ; M_{\text {Victimized by the ingroup }}=2.22$ ). This suggests that our manipulation was not simply increasing overall salience of ingroup victimhood.

Competitive victimhood. As predicted, a similar analysis of our competitive victimhood composite yielded significance, $F(2,29)=3.43, p=.04, \eta^{2}=.19 .{ }^{2}$ Pairwise comparisons revealed that, as predicted, participants in the victimized-by-the-ingroup condition engaged in significantly more competitive victimhood $(M=4.74, S D=.72)$ compared to participants in the non-victimized $(M=3.57, S D=1.28 ; t(29)=2.37, p=.02)$ and victimized-by-another-group conditions $(M=3.69, S D=1.1 ; t(29)=2.25, p=.03)$. Means for the non-victimized and victimized-by-another-group condition participants did not differ, $t<1, p=.78$ (see Figure 2 for a graphical depiction of these results).

Perceptions of victim material entitlement. To determine if competitive victimhood or any effects of condition were related to perceptions of the victim outgroup as materially entitled, we performed the same ANOVA on our single-item measure of victim entitlement. The effect of condition was non-significant, $F<1, p=.67\left(M_{\text {Non-victimized }}=3.50 ; M_{\text {Victimized by another group }}=4.08\right.$; 
$\left.M_{\text {Victimized by the ingroup }}=3.89\right)$. Furthermore, perceptions of the victim outgroup as materially entitled were not significantly correlated with competitive victimhood claims, $r=.01, p=.94$.

$\mathrm{KU}$ undergraduates who were exposed to a portrayal of KU staff as victimized by the ingroup engaged in more competitive victimhood than undergraduates exposed to a portrayal of KU staff as non-victimized or as victimized by another group (KU administrators). Portrayal of the outgroup affected competitive victimhood specifically, and not noncompetitive perceptions of the ingroup as victimized without reference to other groups. Furthermore, participants responded to accusations of ingroup harmdoing by competing for victim status relative not only to the target outgroup, but to all relevant outgroups.

While providing a conceptual replication of the competitive victimhood effect from Study 1 in a different intergroup context, these results also make several advances. First, the fact that competitive victimhood did not occur when the outgroup was portrayed as undeservedly victimized by another group supports the claim that competitive victimhood is a unique response to the moral identity threat posed by accusations of ingroup harmdoing. Second, distinguishing competitive from noncompetitive victimhood claims provides direct evidence for the importance of the hypothesized moral comparative aspect of competitive victimhood. Third, by observing competitive victimhood in a non-dichotomous intergroup context, we were able to determine that motivated competitive victimhood in the face of moral threat occurs in reference to all relevant outgroups, and not only in relation to the target outgroup, further establishing the social comparative aspect of this phenomenon.

\section{General Discussion}

Two studies examining two different intergroup contexts demonstrated that, in response to accusations of ingroup harmdoing, members of higher status groups compete for ingroup 
victim status relative to other groups. In Study 1, men exposed to a portrayal of women as undeservedly victimized by men were more likely (than men exposed to portrayals of women as non-victimized or self-victimized) to claim that men are discriminated against compared to women. In Study 2, undergraduates accused of discriminating against university staff were more likely (than undergraduates exposed to portrayals of staff as non-victimized or victimized by administrators) to claim that their group is discriminated against compared to several relevant outgroups (staff, faculty, and graduate students). Taken together, these studies suggest that competitive victimhood is contingent on the threat implied by ingroup responsibility for outgroup victimization, and does not follow from information suggesting that the outgroup itself or a third group is responsible for the outgroup's victimization. Furthermore, these studies showed competitive victimhood to be independent of perceptions of material benefits to be gained from making claims to victimization, and noncompetitive perceptions of the ingroup as generally victimized.

The present research identifies competitive victimhood as one strategy individuals use to defend against accusations that their ingroup has committed illegitimate harm. Future research is required to better establish the theorized process behind competitive victimhood. For instance, if competitive victimhood is indeed a response to an induced moral identity threat, the effect of a threat manipulation on competitive victimhood should be mediated by some measured feeling of threat or anxiety in connection with the ingroup. Furthermore, if claiming relative victim status does in fact restore or boost moral credentials after accusations of ingroup harmdoing, then we should observe competitive victimhood leading to outcomes such as an inflated sense of ingroup morality or entitlement. Another important question for future research is where competitive victimhood stands in relation to other established strategies - such as victim-blaming cognitions 
- known to be used in response to allegations of outgroup victimization. Given that other strategies exist for coping with such threats, when will competitive victimhood be preferred over other modes of identity defense?

\section{A future direction: Competitive victimhood versus victim-blaming}

Competitive victimhood is one strategy individuals use to counter the moral threat implied by accusations of ingroup harmdoing. However, as alluded to in the Introduction, there are many ways of maintaining or restoring ingroup moral credentials when confronted with information suggesting that an outgroup has been illegitimately victimized by the ingroup. Indeed, competitive victimhood might not be the most straightforward or commonly preferred strategy for coping with such accusations, given that victim status, though often morally enhancing, can have negative connotations. Theory (Harvey, 1995; Ryan, 1976) and research (e.g., Miron et al., 2006) suggest that people often deal with accusations that their group has victimized another by simply refuting the claim with a variety of legitimizing or "victimblaming" cognitions. Such cognitions include: claiming that the alleged harm suffered by the outgroup either did not occur or was not moral harm (i.e., the harm arose from legitimate or unavoidable circumstances); claiming that any harm that did occur was at least partly the fault of the outgroup and therefore is deserved; and/or claiming that the outgroup is strategically using claims to victimhood to achieve illegitimate ends (Harvey, 1995). By employing such legitimizing cognitions, individuals can immediately defuse any threat that might have been inherent in accusations of ingroup harmdoing.

When will individuals prefer to use a victim-blaming over a competitive victimhood strategy in response to threats to the ingroup's moral identity? Cole (2007) identifies two potentially important factors. The first is the apparent objectivity of the claim to victimization by 
the ingroup. If there is seemingly incontrovertible evidence suggesting that the ingroup has in fact been victimizing the outgroup, then it is unlikely that ingroup members will employ a victim-blaming strategy to dispute the outgroup's claim to victimhood. Rather, when the outgroup's claim seems indisputable, it is more likely that ingroup members will acknowledge the claim but defend against its moral implications by engaging in competitive victimhood.

A second, more subtle factor becomes important when the outgroup's claim to victimization has not been indisputably established. Cole (2007) argues that, in the absence of clear objectivity regarding an outgroup victimhood claim, individuals make a heuristic decision about the legitimacy of the claim based on a rough characterization of the outgroup. Specifically, Cole posits that two distinct "schemas" for classifying victims have developed in modern Western society: the schema of the "good" and the "bad" victim. The good victim type is characterized by silence and perseverance in the face of victimization; despite the reality of her suffering, the good victim does not complain or seek redress, but bears discrimination with quiet “dignity," and sometimes even sees her victimization as a source of character-building strength. This victim type is referred to as "good" from the perspective of the dominant social group because such an attitude towards victimization is relatively non-threatening to the perpetrator. Alternatively, the bad victim engages in open complaint regarding her status, seeking to establish an "ethical relationship" with the perpetrator in which the perpetrator acknowledges wrongdoing, and the victim is thereby accorded moral credentials and possibly even material reparations (see also Moscovici \& Pérez, 2009). Obviously, this victim type is labeled "bad" from the dominant group perspective because victims of this sort actively seek recognition from perpetrators of their moral debt. Consistent with this view, Kaiser and Miller (2003) have empirically demonstrated 
that majority group members dislike minority group members who make open accusations of discrimination.

According to Cole (2007), in the absence of inarguable objective evidence concerning a claim to victimhood, people will judge the legitimacy of a group's alleged victim status based solely on their classification of the group as fitting either the good or bad victim type. Two inherent errors of judgment make this process of reaching decisions about the legitimacy of a group's victim status rather dubious. First, it should be clear that whether a group or individual fits the good or bad victim type has nothing to do with the presence or absence of actual discrimination against the group; this designation is only concerned with how the potential victim behaves in response to real or imagined victimization. Second, this heuristic clearly puts the potential victim in an ironic double-bind: the moment a group seeks acknowledgment of their victim status, they become bad victims, and the legitimacy of the victim status they are seeking becomes stillborn. Regardless, Cole asserts that dominant group members make decisions about the legitimacy of victimhood claims in this way, no doubt in large part because they are motivated to classify potential victims as bad and thereby absolve themselves of potential moral debt. Where objective evidence is not directly apparent, people tend to see those who are seeking acknowledgment of their victimhood as bad victims who must have ulterior motivations for undeserved moral credentials, pity, or reparations. When the group fits the good victim type, however, claims to victimhood cannot be tarnished by victim-blaming accusations of insidious motives, and the positive moral status of victimhood remains intact.

Cole's analysis thus offers two predictions concerning when dominant group members are more likely to respond to accusations of harmdoing with a victim-blaming versus a competitive victimhood strategy. First, as stated, when the objectivity of the outgroup's victim 
status cannot be disputed, the legitimacy of claims to victimhood in general remains intact and dominant group members are likely to respond to the accusation by shoring up their own relative victim status, decreasing the potential moral gap. Second, when the objectivity of the outgroup's victimhood has not been clearly established, classification of the outgroup as either good or bad victims should determine whether dominant group members respond to an accusation by competing for good victim status or derogating bad victims. If outgroup members are behaving like good victims, the legitimacy of their status remains intact, and dominant group members should again respond by competing for victim status. However, if outgroup members can be classified as bad victims, then the legitimacy of their threatening claim to victimhood need never be acknowledged by dominant group members, who can instead defuse any potential moral threat by simply engaging in victim-blaming strategies without incurring any of the potential costs of claiming victimhood.

In the current studies, participants were not given the opportunity to blame the victim or deny the legitimacy of the outgroup's victim status. However, in each study objective scientific evidence was offered in support of the claim to the outgroup's victimhood, so we would have expected participants to pursue competitive victimhood over victim-blaming strategies when the ingroup was accused even if the other option had been available. In a study currently underway, we are attempting to directly test the moderating influence of the perceived legitimacy of the outgroup's victim status on the preference for competitive victimhood versus victim-blaming defenses.

Investigating the process once more in the context of the university power hierarchy, with university staff as the victimized outgroup, we are conducting a 2 (perpetrator: undergraduates vs. administrators) X 3 (legitimacy of outgroup victimhood: objective evidence vs. good victim 
vs. bad victim) between-subjects experiment. Specifically, undergraduate participants read a fabricated campus newspaper article containing both of our manipulations. In all conditions, university staff are described as victimized; however, in three conditions, the ingroup (undergraduates) is the perpetrator group, while in the three remaining conditions another group (administrators) is the perpetrator. Our second variable is manipulated in the following manner: in the objective evidence condition, university staff are making a claim to victimhood for which they have clear evidence (e.g., videotape records); in the good victim condition, no objective evidence is presented, but the staff have good victim status because while they are silent about their victimization, a third party (a local labor organization) is making a victimhood claim for them; and in the bad victim condition, the staff are making their own claim to victimization without objective evidence. After reading the newspaper article, participants are given the opportunity to engage in both competitive victimhood (measured as in Study 2) and victimblaming strategies (minimizing the harm, claiming that the outgroup is partly responsible, and attributing ulterior motives to the outgroup for claiming victimhood; Harvey, 1995). The order of presentation of these measures is counterbalanced to control for any possible order effects.

If Cole's analysis is correct, we should observe an interactive effect of our independent variables on both the competitive victimhood and victim-blaming dependent measures. In the case of competitive victimhood, we would expect participants to pursue this strategy when the ingroup is accused and when there is either objective evidence or the outgroup fits the good victim type. Alternatively, we would expect to see greater use of the victim-blaming strategy when the ingroup is accused and the outgroup fits the bad victim type. Such evidence would provide strong support for the theorized importance of perceptions of the outgroup's claim to 
victimhood as legitimate in determining whether competitive victimhood will occur in response to accusations of ingroup harmdoing.

\section{Broader implications}

Conceptions of the ingroup's collective victimhood have historically been an important source of identity for marginalized groups or groups in intractable conflicts (Volkan, 1997), and appear to have become an increasingly positive source of identity in recent periods as victim status has gained moral status (Moscovici \& Pérez, 2009). While victim status has not previously been an important component of identity for dominant group members (Nealon, 2000), the present work shows that members of objectively higher status groups will engage in competitive victimhood at least temporarily to defend the ingroup against moral threat. This evidence certainly speaks to the emerging viability of competitive victimhood as a strategy for establishing or defending group moral credentials. But it also further suggests the possibility that even some dominant group members may be beginning to incorporate aspects of victim status into their identity. As mentioned in the Introduction, some dominant group members have begun to resent widespread acknowledgment of the legitimacy of minority groups' victim statuses, and to see themselves as the "true victims" of corrective policies like welfare, sexual harassment legislation, affirmative action, and so on (Cole, 2007; Lynch, 1989). Nealon (2000) argues that such perceptions are becoming an important aspect of the identity of those he classifies as "angry white males:" dominant group members who see themselves as the only real victims in a society of alleged victims. Future research might investigate the extent to which competitive claims to victimhood, which have their origins in the moral threat implied by accusations of ingroup harmdoing, are actually becoming an important identity aspect for even dominant group members in the modern cultural climate. 
This research might be especially important because, as Nealon (2000) suggests, the competition of dominant group members for victim status may be a serious impediment to rectifying the situation of lower status groups in society. As the aforementioned research by Zitek et al. (2010) and Wohl and Branscombe (2008) suggests, perceiving the ingroup as relatively victimized should elicit feelings of entitlement as well as forgiveness for ingroup transgressions, and reduce empathic reactions to the suffering of others. If dominant group members are indeed experiencing a heightened sense of ingroup righteousness as a result of competitive victimhood processes, this should decrease their motivation to take action to aid more objectively victimized groups in society.

The present phenomenon should also be considered from the perspective of members of marginalized groups. First, there is the question of whether minority group members also engage in competitive victimhood. Some sociological work (Todorov, 2005) suggests that members of minority groups will occasionally engage in competitive victimhood with other minorities, and the theoretical analysis presented here certainly suggests they may do so under conditions of moral threat. Beyond this issue, however, the present work has important implications for members of victimized groups and their (public) relationship to their victimhood. Given that dominant group members may respond to lower status groups' claims to victimhood with competitive victimhood, the question for minority individuals becomes whether presenting the group's image as victimized is an effective means of achieving positive social change.

To take the oppression of women as an example, feminist thinkers have debated this very issue extensively (for a review, see Stringer, 2000). Some critics (e.g., Roiphe, 1993; Wolf, 1993) of "mainstream" feminism have argued that modern women's search for greater equality has been publicly framed and understood too much in terms of a nonproductive identity politics 
of collective victimhood. On the other hand, scholars like Brown (1995) have questioned whether or not the project of acknowledging and eliminating the oppression of women is possible without women as a group making claims to victimhood and establishing an identity that is at least partially founded in an awareness of their victimization. While establishing a positive, legitimate victim identity may be a critical step in the advancement of victimized groups, it is important to recognize that claims to such an identity may be countered by competitive victimhood from the dominant outgroup. New means of conceptualizing victimhood and breaking cycles of competition for victim status should be developed to improve relations between groups and the lives of society's true victims. 


\section{References}

Bar-Tal, D., Chernyak-Hai, L., Schori, N., \& Gundar, A. (2009). A sense of self-perceived collective victimhood in intractable conflicts. International Review of the Red Cross, 91, 229-284.

Bess, J.L., \& Dee, J.R. (2008). Understanding college and university organization (Vol 2). Sterling, VA: Stylus Publishing.

Branscombe, N.R. (1998). Thinking about one's gender group's privileges or disadvantages: Consequences for well-being in women and men. British Journal of Social Psychology, $37,167-184$.

Brown, W. (1995). States of injury: Power and freedom in late modernity. Princeton: Princeton University Press.

Burke, E. (1955). Reflections on the revolution in France (Original work published 1790). Chicago: Gateway Editions.

Carlsmith, J.M, \& Gross, A.M. (1969). Some effects of guilt on compliance. Journal of Personality and Social Psychology, 11, 232-239.

Cole, A.M. (2007). The cult of true victimhood. Palo Alto, CA: Stanford University Press.

Cudd, A.E. (2006). Analyzing Oppression. New York: Oxford University Press.

Doosje, B., Branscombe, N.R., Spears, R., \& Manstead, A.S. (1998). Guilty by association: When one's group has a negative history. Journal of Personality and Social Psychology, $75,872-886$.

D’Souza, D. (1991). Illiberal education: The politics of race and sex on campus. New York: Free Press. 
Ellemers, N., \& Barreto, M. (2009). Maintaining the illusion of meritocracy: How men and women interactively sustain gender inequality at work. In S. Demoulin, J. Leyens, \& J.F. Dovidio, (Eds.), Intergroup misunderstandings: Impact of divergent social realities (pp. 191-212). New York: Psychology Press.

Ellemers, N., Pagliaro, S., Barreto, M., \& Leach, C.W. (2008). Is it better to be moral than smart? The effects of morality and competence norms on decisions to work at group status improvement. Journal of Personality and Social Psychology, 95, 1397-1410.

Fassin, D, \& Rechtman, R. (2009). Empire of trauma: An inquiry into the condition of victimhood. Tr. R. Gomme. Princeton: Princeton University Press.

Gittell, R. (2009). Constrained choices and persistent gender inequality: The economic status of working women in a high-income, low-poverty state with lessons for others. American Behavioral Scientist, 53, 170-192.

Harvey, J. (1995). Categorizing and uncovering "blaming the victim" incidents. Journal of Social Philosophy, 26, 46-65.

Kaiser, C.R., \& Miller, C.T. (2003). Derogating the victim: The interpersonal consequences of blaming events on discrimination. Group Processes and Intergroup Relations, 6, $227-$ 237.

Kobrynowicz, D., \& Branscombe, N.R. (1997). Who considers themselves victims of discrimination? Individual difference predictors of perceived gender discrimination in women and men. Psychology of Women Quarterly, 21, 347-363.

Leach, C.W., Ellemers, N., \& Barreto, M. (2007). Group virtue: The importance of morality (vs. competence and sociability) in the positive evaluation of in-groups. Journal of Personality and Social Psychology, 93, 234-249. 
Lynch, F.R. (1989). White males and the crisis of affirmative action. New York: Greenwood Press.

Mahalingam, R. (2007). Essentialism, power, and the representation of social categories: A folk sociology perspective. Human Development, 50, 300-319.

May, R. (1984). The discovery of being: Writings in existential psychology. New York: W.W. Norton.

Miron, A., Branscombe, N.R., \& Schmitt, M.T. (2006). Collective guilt as distress over illegitimate inequality. Group Processes and Intergroup Relations, 9, 163-180.

Monin, B. (2007). Holier than me? Threatening social comparison in the moral domain. Revue Internationale de Psychologie Sociale, 20, 53-68.

Monin, B., \& Miller, D.T. (2001). Moral credentials and the expression of prejudice. Journal of Personality and Social Psychology, 81, 33-43.

Moscovici, S., \& Pérez, J.A. (2009). A new representation of minorities as victims. In F. Butera \& J.M. Levine (Eds.), Coping with minority status: Responses to exclusion and inclusion. New York: Cambridge University Press.

Nadler, A., \& Shnabel, N. (2008). Instrumental and socioemotional paths to intergroup reconciliation and the needs-based model of socioemotional reconciliation. In A. Nadler, T.E. Malloy, \& J.D. Fisher (Eds.), The social psychology of intergroup reconciliation (pp. 37-56). New York: Oxford University Press.

Nealon, J.T. (2000). Performing resentment: White male anger; or, "lack" and Nietzschean political theory. In A.D. Schrift (Ed.), Why Nietzsche Still? (pp. 274-292). Berkeley: University of California Press. 
Nietzsche, F.W. (2004). On the genealogy of morals (Original work published 1887). In G. Marino (Ed.), Basic writings of existentialism (pp. 111-192). New York: Random House.

Noor, M., Brown, R., \& Prentice, G. (2008). Prospects for intergroup reconciliation: Socialpsychological predictors of intergroup forgiveness and reparation in Northern Ireland and Chile. In A. Nadler, T.E. Malloy, \& J.D. Fisher (Eds.), The social psychology of intergroup reconciliation (pp. 97-116). New York: Oxford University Press.

Nucci, L.P. (1996). Morality and the personal sphere of action. In E.S. Reed, E. Turiel,, \& T. Brown (Eds.), Values and knowledge (pp. 41-60). Mahwah, NJ: Lawrence Erlbaum.

Rank, O. (1996). A psychology of difference: The American lectures. Princeton: Princeton University Press.

Roiphe, K. (1993). The morning after: Sex, fear, and feminism. London: Hamish Hamilton. Ryan, W. (1976). Blaming the victim. New York: Vintage Books.

Sachdeva, S., Iliev, R., \& Medin, D.L. (2009). Sinning saints and saintly sinners: The paradox of moral self-regulation. Psychological Science, 20, 523-528.

Schmitt, M.T., Branscombe, N.R., \& Postmes, T. (2003). Women's emotional responses to the pervasiveness of gender discrimination. European Journal of Social Psychology, 33, $297-$ 312.

Strassel, K.A. (2001, March 23). Another group, another claim to victimhood. Wall Street Journal, p. W17.

Stringer, R. (2000). “A Nietzschean Breed”: Feminism, victomology, ressentiment. In A.D. Schrift (Ed.), Why Nietzsche Still? (pp. 247-273). Berkeley: University of California Press. 
Tajfel, H., \& Turner, J.C. (1986). The social identity theory of intergroup conflict. In S. Worchel \& W.G. Austin (Eds.), The psychology of intergroup relations (7-24). Chicago: Nelson Hall. Todorov, T. (2005). Mémoire du mal, tentation du bien. Paris: Robert Laffont.

Tompkins, P.K., Fisher, J.Y., Infante, D.A., \& Tompkins, E.L. (1975). Kenneth Burke and the inherent characteristics of formal organizations: A field study. Speech Monographs, 42, $135-142$

United Nations. (2007). Report of the Committee on the Elimination of Discrimination against Women (Issue 38 of Official Records). New York: United Nations Publications.

Vandello, J.A., Goldschmied, N.P., \& Richards, D.A.R. (2007). The appeal of the underdog. Personality and Social Psychology Bulletin, 33, 1603-1616.

Volkan, V. (1997). Bloodlines: From ethnic pride to ethnic terrorism. New York: Farrar, Straus, \& Giroux.

Williams, B. (1993). Shame and necessity. Berkeley, CA: University of California Press.

Wohl, M.J.A., \& Branscombe, N.R. (2008). Remembering historical victimization: Collective guilt for current ingroup transgressions. Journal of Personality and Social Psychology, 94, 988-1006.

Wohl, M.J.A., \& Branscombe, N.R. (2009). Group threat, collective angst, and ingroup forgiveness for the war in Iraq. Political Psychology, 30, 193-217.

Wohl, M.J.A., Branscombe, N.R., \& Klar, Y. (2006). Collective guilt: Emotional reactions when one's group has done wrong or been wronged. European Review of Social Psychology, $17,1-37$.

Wolf, N. (1993). Fire with fire: The new female power and how it will change the $21^{\text {st }}$ Century. New York: Chatto \& Windus. 
Zitek, E.M., Jordan, A.H., Monin, B., \& Leach, F.R. (2010). Victim entitlement to behave selfishly. Journal of Personality and Social Psychology, 98, 245-255. 


\section{Footnotes}

1. Our measure of male identification was included as a potential moderator, given that high group identifiers are often more defensive in response to threats (e.g., Doosje, Branscombe, Spears, \& Manstead, 1998). We ran regression analyses to determine whether the effects of the outgroup portrayal manipulation might be moderated by the extent to which participants identified as a man (note that the distribution was negatively skewed, $M_{\text {Grand }}=5.67$ on a 7 -point scale). Specifically, competitive victimhood scores were regressed onto outgroup portrayal (contrast-coded: victimized by the ingroup $=1$, non-victimized $=-.5$, self-victimized $=-.5$ ), identification as a male (centered and continuous), and their interaction. This analysis revealed only the main effect for outgroup portrayal, $\beta=.32, t(45)=2.29, p=.03$ (all other $t \mathrm{~s}<1, n s$ ).

2. To determine whether there was any difference in competitive victimhood claims as a function of reference group, we also separately analyzed competition with only the target outgroup (KU staff). We found a marginally significant effect of condition, $F(2,29)=3.17, p=.06, \eta^{2}=.17$, such that participants were more likely to engage in competitive victimhood in the victimizedby-the-ingroup compared to the other conditions $\left(M_{\text {Victimized by the ingroup }}=4.56, M_{\text {Non-ictimized }}=3.20\right.$, $\left.M_{\text {Victimized by another group }}=3.53\right)$. Overall, the findings from Study 2 suggest that when individuals are motivated to engage in competitive victimhood to compensate for harm done to an outgroup, they will compete not only with the relevant outgroup but with other reference groups as well. 
Appendix 1: Online news article outgroup portrayal manipulation (Study 1)

Non-victimized condition

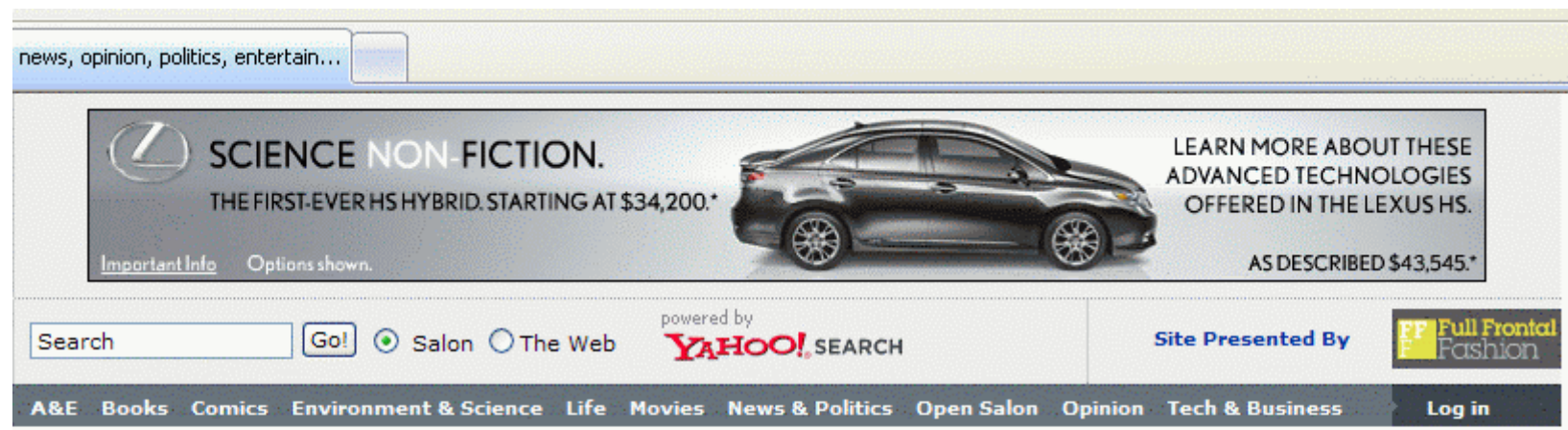

Women no longer victims of discrimination in our society

Posted Sunday, August 23, 2009

As you are probably aware, in the U.S., opportunities are open for all individuals, regardless of gender. Women and men benefit from equal opportunities in employment, salary, education, politics, and in the courtroom. In spite of some common misbeliefs to the contrary, across diverse types of jobs and salary levels, women and men have been found to earn the same incomes for the same types of jobs. Women and men experience the same social opportunities, and the same average level of career success.

Recent sociological research indicates that women are no longer likely to encounter discrimination in modern Western society. Less than $5 \%$ of men and women endorse sexist attitudes, and almost all U.S. citizens claim they would not discriminate against someone of the opposite sex if given the chance. These and other studies clearly indicate that our society is now essentially free from discrimination of women.

Note. The article has been resized for purposes of inclusion in this document. The version viewed by participants was larger in size. 


\section{Self-victimized condition}

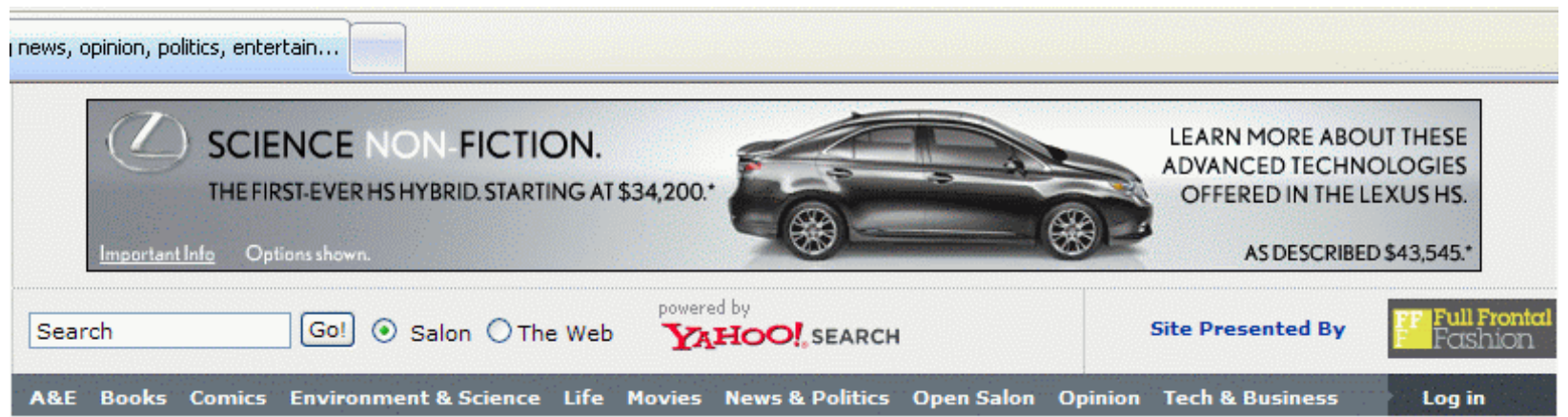

Women victims of discrimination; but they're responsible!

Posted Sunday, August 23, 2009

As you are probably aware, women in the U.S. still face widespread discrimination in many important areas of life. Women are still routinely the victims of discrimination and inequality in employment, salary, education, politics, and in the courtroom. Across diverse types of jobs and salary levels, women commonly make only $75 \%$ of what men do, even for the same job and when they have equal amounts of experience. Women also have fewer social opportunities than men, and experience biological barriers (such as pregnancy) to career success.

Recent sociological research indicates that the discrimination most modern women face is the direct result of female biology. Close to $95 \%$ of women do not believe themselves physically capable of performing some jobs traditionally done by men, and most women claim it is more important for them to raise a family than to have a successful career. A series of conclusive studies indicate that gender-based discrimination is the result of choices made by women, based largely on their biological differences from men. In other words, because of certain inherent characteristics, women experience discrimination despite the fact that men are not responsible for its occurrence.

Note. The article has been resized for purposes of inclusion in this document. The version viewed by participants was larger in size. 


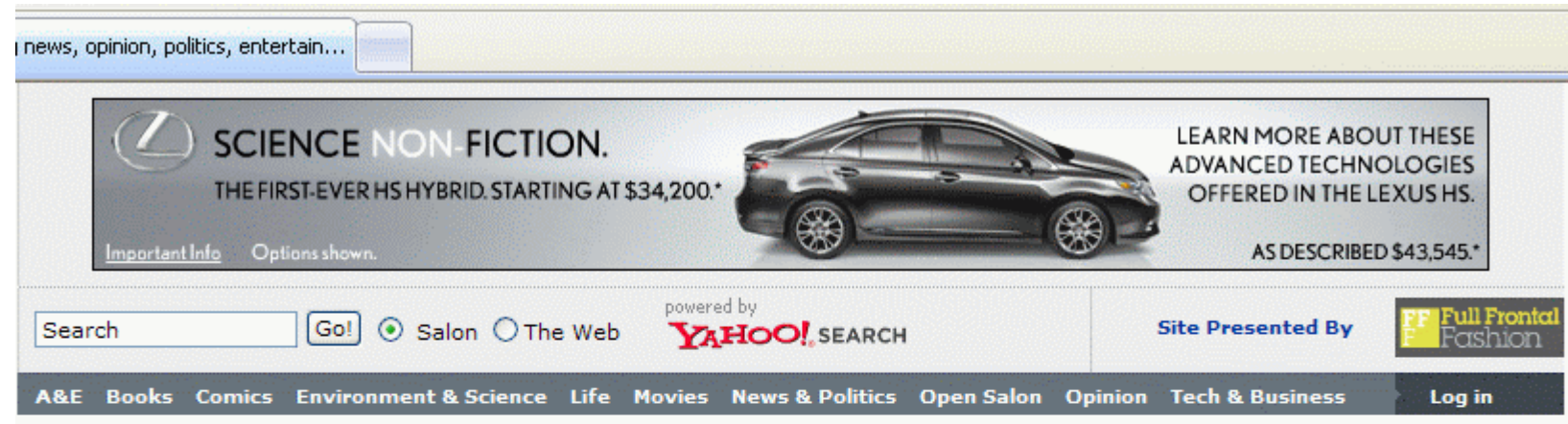

\section{Women victims of discrimination; men responsible}

Posted Sunday, August 23, 2009

As you are probably aware, women in the U.S. still face widespread discrimination in many important areas of life. Women are still routinely the victims of discrimination and inequality in employment, salary, education, politics, and in the courtroom. Across diverse types of jobs and salary levels, women commonly make only $75 \%$ of what men do, even for the same job and when they have equal amounts of experience. Women also have fewer social opportunities than men, and experience male sexism as a barrier to career success.

Recent sociological research indicates that the discrimination most modern women face is the direct result of sexism on the part of men. Close to $95 \%$ of men endorse some sexist attitudes (i.e., they agree with the idea that a woman could never fill a leadership role as well as a man), and $65 \%$ claim they would discriminate against a woman if given the chance. A series of conclusive studies indicate that gender-based discrimination is the result of the prejudices and behaviors of men at all levels of society. In other words, because men have an active interest in maintaining their social advantages, discrimination of women continues to occur through the intentional acts of men.

Note. The article has been resized for purposes of inclusion in this document. The version viewed by participants was larger in size. 
Appendix 2: Transcripts of audio reports for outgroup portrayal manipulation (Study 2)

\section{Non-victimized condition}

Researcher: A study was recently conducted to examine the daily experience and treatment of staff on the University of Kansas campus. This study was the result of collaboration between researchers in the psychology, sociology, and economics departments here at $\mathrm{KU}$, as well as with visiting researchers from other universities. The research process involved interviews and non-obtrusive observation of over $100 \mathrm{KU}$ staff members. This included custodial and office staff, as well as non-student employees in the libraries, museums, and campus eateries. Additionally, members of the faculty and administration, as well as students themselves, were interviewed and completed surveys regarding their experiences with the university staff.

The study found that, overall, the KU staff receives treatment that is comparable to that of the members of many other university staffs around the country. In particular, KU staff members receive fair treatment from students and administrators. Staff members sometimes receive public compliments and verbal acknowledgments for their work. In addition, most people on campus follow basic rules of etiquette, leaving campus bathrooms and other public spaces relatively clean, which makes staff duties easier.

More than $75 \%$ percent of KU students and administrators report somewhat positive attitudes towards the staff, calling them "motivated" and "efficient." Eighty percent of campus staff members report that they are well treated almost every day. The following is a short segment from a recorded interview with one custodial staff member...

Interviewer: So, how would you describe the treatment you receive on campus? 
Staff member: Well, overall I'd say it's pretty good. I've worked in a lot of different jobs, I've worked at a lot of different universities for a...bunch of years now, and I feel treated just as good here at KU as anywhere else. Most people are fairly decent to you.

Researcher: In general, the findings of this study indicate that the majority of KU staff members are happy with the treatment they receive on campus, and the good campus atmosphere is the primary source of their feelings.

\section{Victimized-by-another-group condition}

Researcher: A study was recently conducted to examine the daily experience and treatment of staff on the University of Kansas campus. This study was the result of collaboration between researchers in the psychology, sociology, and economics departments here at $\mathrm{KU}$, as well as with visiting researchers from other universities. The research process involved interviews and non-obtrusive observation of over $100 \mathrm{KU}$ staff members. This included custodial and office staff, as well as non-student employees in the libraries, museums, and campus eateries. Additionally, members of the faculty and administration, as well as students themselves, were interviewed and completed surveys regarding their experiences with the university staff.

The study found that, overall, the KU staff suffers worse treatment than the members of many other university staffs around the country. In particular, KU staff members receive harsh treatment from the campus administration. Representatives of the administration were routinely observed publicly humiliating or verbally abusing campus staff. In addition, KU administrators routinely ignore basic rules of etiquette, leaving campus bathrooms and other public spaces dirty and full of waste for the staff to clean up. 
More than $75 \%$ percent of KU administrators report negative attitudes towards the staff, calling them "lazy," "annoying," and "slow." Eighty percent of campus staff members report that they are mistreated by administrators on an almost daily basis. The following is a short segment from a recorded interview with one custodial staff member...

Interviewer: So, how would you describe the treatment you receive on campus?

Staff member: Well, overall I'd say it's pretty bad. I've worked in a lot of different jobs, I've worked at a lot of different universities for a... bunch of years now, but I never been treated worse than here at KU. The administrators here...they just walk all over you!

Researcher: In general, the findings of this study indicate that the majority of KU staff members are not happy with the treatment they receive on campus, and the administration is the primary source of their mistreatment.

\section{Victimized-by-the-ingroup condition}

Researcher: A study was recently conducted to examine the daily experience and treatment of staff on the University of Kansas campus. This study was the result of collaboration between researchers in the psychology, sociology, and economics departments here at $\mathrm{KU}$, as well as with visiting researchers from other universities. The research process involved interviews and non-obtrusive observation of over $100 \mathrm{KU}$ staff members. This included custodial and office staff, as well as non-student employees in the libraries, museums, and campus eateries. Additionally, members of the faculty and administration, as well as students themselves, were interviewed and completed surveys regarding their experiences with the university staff.

The study found that, overall, the KU staff suffers worse treatment than the members of many other university staffs around the country. In particular, KU staff members receive harsh 
treatment from the undergraduate student population. Undergraduates were routinely observed publicly humiliating or verbally abusing campus staff. In addition, KU undergraduates routinely ignore basic rules of etiquette, leaving campus bathrooms and other public spaces dirty and full of waste for the staff to clean up.

More than $75 \%$ of undergraduate students report negative attitudes towards the staff, calling them "lazy," "annoying," and "slow." Eighty percent of campus staff members report that they are mistreated by undergraduates on an almost daily basis. The following is a short segment from a recorded interview with one custodial staff member...

Interviewer: So, how would you describe the treatment you receive on campus?

Staff member: Well, overall I'd say it's pretty bad. I've worked in a lot of different jobs, I've worked at a lot of different universities for a...bunch of years now, but I never been treated worse than here at KU. The undergraduates here...they just walk all over you!

Researcher: In general, the findings of this study indicate that the majority of KU staff members are not happy with the treatment they receive on campus, and the undergraduate population is the primary source of their mistreatment. 
Figure 1. Competitive victimhood as a function of outgroup portrayal condition (Study 1).

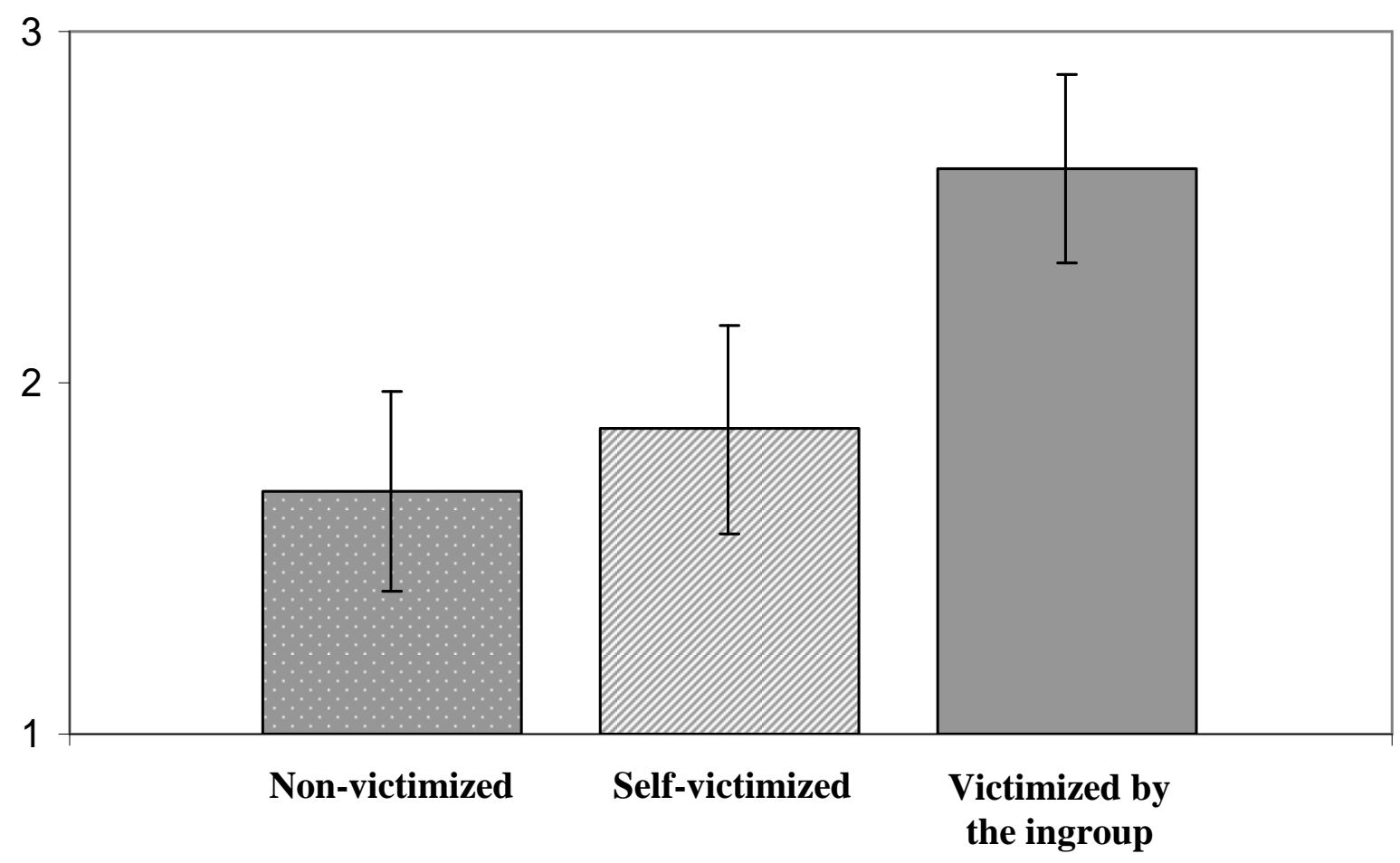

Note. Scale ranged from 1-7. A response of 4 signified, "In society, compared to women, men experience as much discrimination.” Bars represent standard errors. 
Figure 2. Competitive victimhood as a function of outgroup portrayal condition (Study 2).

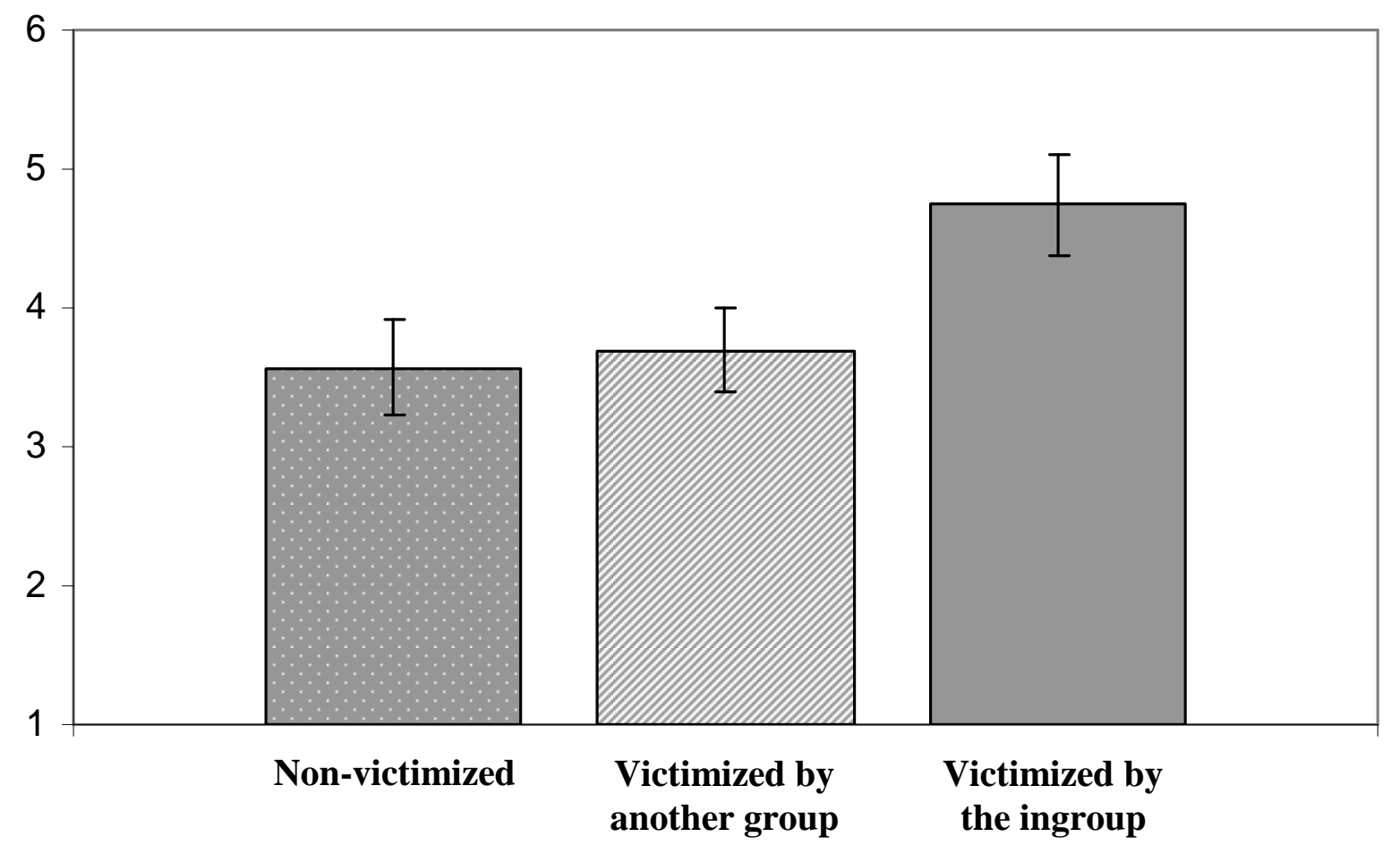

Note. Scale ranged from 1-7. Bars represent standard errors. 